\title{
Od multikulturalismu k občanské integraci. Změny v západoevropských politikách integrace přistěhovalcư
}

\author{
Andrea Baršová - Pavel Barša
}

Tématem tohoto prŕspěvku jsou spory o multikulturní politiky vůči přistěhovalcům v současné západní Evropě. ${ }^{1}$ Pokusíme se doložit tři teze.

(1) Současný přesun těžiště integračních politik od zohledňování skupinové odlišnosti (multikulturalismus) k důrazu na individuální občanskou integraci - nejpatrnější ve Velké Británii a v Nizozemí - není jen výrazem populistické xenofobie, jak tvrdí někteří liberální a levicoví komentátoři, ale reaguje na reálné fenomény sociální segregace a protizápadní indoktrinace (především fundamentalistickým islámem), jimiž jsou postiženy některé segmenty přistěhovalého obyvatelstva.

(2) Obrat v politikách nesvědčí ani tak o porážce multikulturalismu - jehož mnohé přístupy se dnes staly součástí mainstreamového vědomí a institucí -, jako spíše o posunu v problematice integrace přistěhovalců. Skutečný problém již neleží v konfliktu moderní kultury evropských národů s tradiční kulturou přistěhovalců, ale v konfliktu liberálních institucí Evropanů s náboženskými fundamentalistickými ideologiemi, šiŕícími se obzvláště, byt' ne výlučně, mezi přistěhovalci.

(3) Ačkoliv česká integrační politika nebyla zatím zdaleka vystavena těmto konfliktům ve stejné míre v jaké jí byli nuceni čelit starší členové EU, za zhruba šest let své existence prošla obdobným vývojem od multikulturalismu k občanské integraci - byt' zatím spíše v dikci úředních dokumentů. Implementace vládních strategií do konkrétních opatření je totiž jen na počátku.

\section{Kanada a Austrálie: multikulturalismus jako státní ideologie}

Abychom zařadili evropskou diskusi o integraci a multikulturalismu do širšího kontextu, zmíníme se napřed o dvou zemích Nového světa - Kanadě a Austrálii -, kde se multikulturalismus stal nejen státní politikou, ale také státní ideologií. V obou zemích ovšem předcházela multikulturní politiku multikulturní realita. Přítomnost původních národů s jejich stěží popiratelnými nároky na uchování identity a tradičního způsobu života výrazně přispěla $\mathrm{k}$ tomu, že - poté, co byl odmítnut tradiční rasismus - byla multikulturní povaha těchto přistěhovaleckých společností nejen politicky uznána, ale kladně zhodnocena jako zdroj národní hrdosti. ${ }^{2}$ K tomu přispělo i to, že na rozdíl od USA chyběl v Kanadě a Austrálii silný zakladatelský mýtus (válka za nezávislost, přijetí Ústavy), který by vytvořil zcela novou národní identitu. Kladný poukaz k soužití různých skupin tak fungoval jako symbolická značka odlišnosti těchto společností od ostatních. Můžeme shrnout, že kanadské a australské přijetí multikulturní 
politiky jako oficiálního kréda $\mathrm{v} 70$. letech 20 . století bylo jednou z mála schůdných odpovědí na potřebu férového řešení vztahu k původním obyvatelům na straně jedné a potřebu sjednocující národní ideologie na straně druhé.

Kanada se k multikulturalismu přihlásila již roku 1971 a stvrdila to roku 1988 přijetím zákona o kanadském multikulturalismu. ${ }^{3}$ Ten vychází z teze, že kanadský národ vznikl spojením kultury původních obyvatel a dvou osadnických evropských kultur - britské a francouzské. Kulturní, etnická a jazyková různost je pokládána za cenné národní dědictví a základní kámen kanadské kolektivní identity. Multikulturalismus má být kanadským př́spěvkem do světové civilizační pokladnice - vývozním artiklem, který si mohou osvojit i jiné národy. (Vztah Kanady k multikulturalismu tak připomíná vztah USA k neomezené svobodě slova.)

Prakticky zahrnuje kanadský multikulturalismus standardní opatření, jakými jsou dvojjazyčnost a uplatňování antidiskriminačních politik, ale i novátorské postupy, např́íklad začlenění vědění původních obyvatel do vědeckého bádání při studiu oceánů či ekosystémů. Podle oficiálního kréda poskytuje multikulturní politika Kanadě výhody ve srovnání $\mathrm{s}$ jinými státy. Přistěhovalci pocházející z mnoha národů světa mají přispívat ke zlepšení zahraničních vztahů. Různé jazyky a kultury mají usnadňovat rozvoj obchodu. Konfrontace vědění $\mathrm{z}$ více kulturních okruhů má zase vést k rozvoji neotřelých pohledů na ekonomické, politické i sociální otázky.

Pojetí multikulturalismu jako státní ideologie je typické také pro Austrálii. Od roku 1973, kdy multikulturalismus nahradil politiku „bílé Austrálie“ v roli oficiální národní doktríny, si jeho obsah uzpůsobují levicové i pravicové vlády podle svých potřeb. Nejnovější dokument vlády konzervativního premiéra Johna Howarda „Multikulturní Austrálie: spojeni v různosti“ načrtávající program na roky 2003-2006, poukazuje ke kosmopolitnímu profilu australského obyvatelstva a definuje multikulturalismus jako prostředek maximalizace kulturních a hospodárských výhod z koexistence různých kulturních skupin. Současně zmiňuje i meze různosti, jimiž jsou loajalita $\mathrm{k}$ australskému národu a respekt $\mathrm{k}$ základním strukturám a principům demokratické společnosti, jako jsou ústava, parlamentní demokracie, svoboda slova a náboženství, angličtina jako národní jazyk, vláda práva a rovnost.

Můžeme tedy shrnout, že multikulturalismus jako doktrína a politika zemí Nového světa vychází z toho, že společnost je skupinově různorodá a že úkolem státu je tuto rozmanitost udržet a rozvíjet. Tato kladně zhodnocená různost je však zarámována loajalitou př́slušníků různých kulturních skupin ke společnému občanskému národu, jehož jazyk a veřejnou kulturu sdílí všichni, at již na nižší úrovni patří k jakékoliv zvláštní skupině. Bez tohoto druhého pólu by multikulturalismus nikdy nemohl plnit roli oficiální ideologie národního státu. Pro zdůraznění národních, partikulárních hranic své podpory kulturní různosti mluví oficiální dokumenty vždy o „kanadském“ nebo „,australském“ multikulturalismu. Podpora různosti však má i hranice univerzalistické, jimiž jsou principy liberálně-demokratické společnosti jako takové.

\section{Nizozemí: vzestup a pád multikulturalismu}

$\mathrm{Na}$ rozdíl od multikulturalismu zemí Nového světa, kde tato ideologie odpovídala na širší společenskou poptávku po vytvoření národní identity, v Evropě se multikulturní politika rozvíjí především v návaznosti na rostoucí imigraci a následnou změnu ve slože- 
ní obyvatel po druhé světové válce. Př́ičiny těchto procesů byly jednak politické - především rozpad koloniálních říší, ${ }^{4}$ jednak ekonomické - nedostatek pracovních sil a nábor statisíců „dočasných“ pracovníků v období hospodářského rozmachu 50. a 60. let 20. století. $\mathrm{V}$ protikladu ke zmíněným přistěhovaleckým zemím přichází v některých zemích západní Evropy - Velké Británii, Nizozemí a Švédsku - multikulturní politika takřka současně s multikulturní realitou či v těsném závěsu za ní. Multikulturalismus jako strategie pluralistické integrace přistěhovalců existuje uvnitř samozřejmého rámce staletími utvářené národní existence, její ústavy, kultury a institucí. Předpoklad, že tento rámec zůstane zachován, je považován za samozrejmý. Státy hlásící se k multikulturní politice ani nepovažují za nutné jej deklarovat.

Vývoj od konce 90. let 20. století ale otřásl samozrrejmostí tohoto prredpokladu. Nedostatečná integrace některých skupin přistěhovalců, fenomény segregace etnických komunit a projevy napětí mezi přistěhovalci a původními obyvateli způsobily, že si hostitelské společnosti začaly uvědomovat, že politické hodnoty a instituce samozřejmé pro starousedlíky takovými nejsou pro novousedlíky. Poplašné signály také vzbudilo zjištění, že často ani neexistují cesty, jak vědomí o těchto hodnotách a institucích přistěhovalcům předat - např́klad když chybí společný jazyk nebo jsou-li jejich děti vzdělávány v de facto segregovaných školách.

Jak bylo zmíněno, $\mathrm{v}$ západní Evropě se $\mathrm{k}$ oficiální multikulturní politice přihlásily výslovně tř̆ země: Velká Británie, Nizozemí a Švédsko (Joppke 2003). ${ }^{5}$ Tzv. „multikulturní“ či ,interkulturní“ postupy byly realizovány v menším rozsahu i v dalších západoevropských zemích. Uplatnily se také na místní úrovni, například ve Frankfurtu či jiných německých městech. Zlatým věkem multikulturalismu byla 80 . léta 20. století. Symbolem vzmachu a pádu multikulturalismu v Evropě se stalo Nizozemí.

Nizozemí mělo tradičně pověst bezpečného přístavu. ${ }^{6}$ Svou prosperitou a otevřeností přitahovalo různé uprchlíky a migranty již od 16 . století. Po konci 2 . Světové války začalo přistěhovalectví, které bylo dědictvím nizozemské koloniální tradice. Vraceli se Nizozemci, kteří žili a pracovali v Indonésii, Surinamu a na Karibských ostrovech. Mezi léty 1945-1965 se vrátilo z Indonésie celkem 300000 osob. Migrace, která následovala po vyhlášení nezávislosti Surinamu v roce 1975, privedla do Nizozemí v následujících dvaceti letech dalších 296000 prristěhovalcủ. Vedle toho probíhal v poválečné době podobně jako v dalších západoevropských zemích nábor pracovních sil, pocházejících převážně ze středomořské oblasti - z Itálie, Španělska, Turecka, Maroka a Jugoslávie. Tato imigrace byla považována za dočasnou, ukázala se však jako trvalá.

Nové menšiny začaly být, podobně jako jinde v Evropě, považovány za problém koncem 70. let 20. století. Vláda na to odpověděla hledáním nové politiky, jejímž hlavním cílem mělo být zajištění jejich rovnosti za současného uchování jejich kulturní identity. V tomto paradigmatu se spojily historické zkušenosti s emancipací dvou původně diskriminovaných skupin - dělníků a katolíků. Tak jako dělníci, i přistěhovalci měli mít právo na rovnost. A tak jako katolíci, také oni měli užívat právo na uchování své kulturní zvláštnosti v rámci vlastních sociálních institucí (Lechner 2002). Multikulturalismus se stal kouzelným slovem integrační politiky. Jedním z opatření byla např́iklad podpora vzdělávání dětí přistěhovalců $\mathrm{v}$ jejich mateřském jazyce. Stát také uznal právo muslimských skupin na zakládání vlastních škol. 
V praxi však tyto politiky nevedly $\mathrm{k}$ dosažení rovnosti mezi přistěhovalci a domácím obyvatelstvem ve vzdělání a ani v sociálním a ekonomickém postavení. Na počátku 90 . let se navíc ve velkých městech (Amsterdam, Rotterdam) začala výrazně projevovat rostoucí rezidenční segregace přistěhovalců.

Joanne van Selm v pojednání Nizozemí: Tolerance pod tlakem (Selm 2003) popisuje situaci koncem 90. let minulého století následovně: „Mnoho lidí se shodlo, že vlastně nechápou, co je multikulturalismus. A pokud si mysleli, že tomu rozumí, tak si nebyli jisti, zda multikulturalismus v praxi funguje“ (Selm 2003: 5). V lidovém pojetí byl multikulturalismus stále více chápán jako zdvořilé ustupování roztahovačnému hostu, jenž vás postupně vytěsňuje z vašeho příbytku. Tak jej líčil např́íklad kontroverzní filmař Theo van Gogh.

Prvním signálem obratu - a předzvěstí „,multikulturní debaty“ - se stalo v Nizozemí přijetí Zákona o integraci nových přistěhovalců v roce 1998, který zavedl povinnou účast každého přistěhovalce ve státem řízeném a financovaném integračním programu. ${ }^{7}$ Program je individualizovaný a hlavní roli při jeho realizaci mají obce. Zahrnuje výuku holandštiny v rozsahu 600 hodin a návštěvu kurzů sociální a pracovní orientace pro všechny nově příchozí. Po roce od zahájení programu je imigrant povinen složit zkoušku z jazyka a sociální orientace. ${ }^{8}$ Přijetí zákona se stalo průlomem. Nastartovalo obrat od multikulturní podpory skupin k individuální integraci a signalizovalo stoupající vliv teze, že nizozemská společnost je v důsledku nezvládnuté integrace ohrožena ztrátou kulturní a sociální soudržnosti.

Rozbuškou, která podnítila národní debatu o multikulturalismu a národní identitě, se stal článek levicového komentátora Paula Scheffera „Multikulturní drama“, publikovaný v celonárodním listu NRC Handelsblad 29. ledna 2000. Závažnost diskuse, jíž Scheffer podnítil, dokládá i to, že nizozemský parlament si v roce 2000 vyčlenil dva dny bez zákonodárné agendy, aby prodiskutoval jím vznesené otázky (Lechner 2002: 2, 16).

Scheffer prolomil mnohá z dosavadních tabu multikulturalismu. Poukázal na to, že běžná rétorika tolerance a inkluze nemůže zakrýt fakt rostoucí etnické segregace. Podle Scheffera bylo jádrem problému to, že multikulturalismus jednostranně upřednostňoval pól různosti před pólem jednoty. Ve snaze o otevřenost vůči přistěhovalcủm ztratilo Nizozemsko smysl pro svou vlastní kulturní a politickou identitu, která by překlenovala identity zvláštních skupin. Bez přihlášení se ke společnému jazyku a tradicím se ztrácí sjednocující rámec pro integraci príichozích. Aby se multikulturní drama nezměnilo v apartheid, je podle Scheffera nezbytné znovu definovat to, co činí společnost „nizozemskou“, a posílit snahy o socializaci imigrantů do nizozemské národní kultury (Lechner 2002: 2).

Debata, kterou Scheffer vyvolal, se brzy proměnila $\mathrm{v}$ diskusi o národní identitě. Co znamená být Holand'anem? Existují nějaké prvky nizozemské společnosti a kultury, které jsou závazné i pro nově příchozí? Podle některých názorů Scheffer spuštěním diskuse vydláždil cestu k úspěchu politickému dobrodruhovi Pimu Fortuynovi, jehož strana (LPF) ${ }^{9}$ se díky své silné protipřistěhovalecké rétorice ve volbách roku 2002 vyhoupla na post druhé nejsilnější strany v zemi (26 křesel, 17,9 \% hlasů). Zavraždění Pima Fortuyna krátce před volbami ani následná vládní krize nezastavily započatý trend. Slovo „multikulturní“ se začalo vytrácet $\mathrm{z}$ vládních dokumentů (Selm 2003). Přistěhovalecká pravidla byla dále přeformulována s důrazem na individuální integraci a osobní odpovědnost těch, kteří se chtějí v Nizozemí trvale usadit. 
Podle návrhu nové integrační legislativy z roku 2004 se přistěhovalci musejí přihlásit k základním hodnotám a normám nizozemské společnosti. Ti, kteří se chtějí přistěhovat trvale, musejí prokázat základní znalost jazyka již před svým příchodem do Nizozemí. Předpokladem pro udělení povolení trvalého pobytu v Nizozemí je pak složení náročnější „,integrační zkoušky“ z jazyka a znalostí nizozemské společnosti do tří a půl roku po složení zkoušky vstupní. Nový model povinné a na výsledek orientované integrace má být uplatněn nejen vůči nově příchozím, ale ( $\mathrm{v}$ poněkud měkčí podobě) vůči všem osobám, které nežily v Nizozemí po dobu osmi let, kdy se na ně vztahovala povinná školní docházka, a u nichž nelze předpokládat dostatečnou znalost jazyka a reálií na základě jiných prokazatelných skutečností. ${ }^{10}$

Zavraždění Theo van Gogha, jehož ve filmařské komunitě přezdívali „nizozemský Michael Moore“, přineslo v debatě o multikulturalismu další posun. Gogha zavraždil 2. listopadu 2004 islámský fundamentalista, kterého k činu podnítil Goghův snímek Submission, expresivně kritizující vztah islámu k ženám. ${ }^{11}$ Vražda a následné žhářské útoky proti mešitám, kostelům a islámským školám ukázaly, že jde o konflikt spíše ideologicko-politický než kulturně-etnický. Ideový profil a motivy Mohammeda Bouyeriho, podezřelého z vraždy Theo van Gogha, nebyly totiž ,,ani tak dílem zanícených imámů z marockého venkova jako spíše dílem informační společnosti Západu“ (Both 2004). Z tohoto hlediska není problémem přistěhovalectví jako takové, ani muslimští přistěhovalci obecně, ale skutečnost, že část muslimských přistěhovalců či jejich špatně integrovaných potomků inklinuje k militantním formám islámu.

Potvrzení, že spíše než o kulturní nebezpečí se jedná o nebezpečí ideologické, můžeme najít ve zprávě From Dawa to Jihad, kterou zpracovalo nizozemské ministerstvo vnitra na podkladě zpráv informačních služeb v prosinci roku 2004. ${ }^{12}$ Podle této zprávy je z jednoho milionu muslimů žijících v Nizozemí 95 \% umírněných. To ale také znamená, že v Nizozemí žije až 50000 potenciálních islamistických radikálů (Gerstenfeld 2005). Ideologickým záměrem radikálních islamistických skupin je rezistence vưči západnímu životnímu stylu a západní politické, ekonomické a kulturní dominanci. Holandská politická i kulturní elita dospěla k závěru, že takový agresivní proud překračuje meze, v nichž lze pěstovat multikulturní dialog. Podobně jako krajně pravicová hnutí či skinheadi, také tento netolerantní směr má být zadržován a potírán, nikoliv tolerován a uznáván.

Alespoň ve třech ohledech se nizozemská kritika multikulturalismu liší od tradiční protipřistěhovalecké rétoriky evropské krajní pravice.

(1) Neodráží jen strach, předsudky a pocit ohrožení nižších tříd, jež dovedou populističtí politikové obratně proměnit ve volební preference. Odráží také obavy a zděšení části středních tříd a politického establishmentu. Psychologický dopad zavraždění Theo van Gogha na tento segment společnosti je srovnáván s šokem z útoků 11. Září v USA.

(2) Mnozí z těch, kteří vyzývají k obraně před cizí „kolonizací“, nezdůrazňují konzervativní, ale liberální hodnoty domácí společnosti - respekt k individuální svobodě a svobodě projevu, rovnost mužů a žen či zplnoprávnění gayů a leseb. To platí i pro kontroverzní postavy tohoto proudu, jakými byli Pim Fortuyn nebo Theo van Gogh. ${ }^{13}$ Tradiční protipřistěhovalecká pravice nemá takové hodnoty ve své výbavě (pokud k nim není prrímo nepřátelská).

(3) Nizozemská „protimultikulturní“ reakce nevidí problém v etnicko-kulturním, ale v ideologicko-náboženském aspektu skupinové různosti. 
Můžeme shrnout: na rozdíl od rétoriky xenofobní pravice není tato vlna kritiky nesena jen obavami nižších tříd, ale také střední třídy a elit; neopírá se o konzervativní, ale o liberální hodnoty a nezdůrazňuje etnickou či rasovou povahu konfliktu, ale jeho ideologické a náboženské zdroje.

\section{Velká Británie: od různosti $\mathrm{k}$ jednotě}

Ve Velké Británii můžeme sledovat podobné posuny ve společenské atmosféře i politikách jako v Nizozemí, byt’ se odehrávají v mezích př́slovečné britské umírněnosti. Původ britského konceptu ,pluralistické integrace“ je spojen s historií a ideou impéria jako politického tělesa, v němž pod společnou střechou koexistují různé etnické a regionální kultury, i když jsou nerovné a podřizené anglické kultuře. Britové ve své koloniální tradici respektovali cizí kultury jako něco, co nemá být zrušeno, ale spíše uhlazeno a inkorporováno pod britskou korunu. Jakmile se v 60. letech 20. století prosadila myšlenka rovné důstojnosti př́slušníků různých kultur, mohl se tento původně nerovný pluralismus proměnit v liberální „,multikulturalismus“ (Barša 2004). Nový model multikulturní integrace definoval v dnes již slavném výroku z května 1966 labouristický ministr vnitra Roy Jenkins: „Integrace neznamená to, že by přistěhovalci ztratili vlastní národní charakteristiky a svou kulturu. Myslím, že v této zemi nepotřebujeme ,tavicí kotel ‘... Přišli bychom tím o ten největší př́ínos, který z imigrace můžeme získat, což by myslím bylo opravdu škoda. Proto definuji integraci nikoliv jako zplošt'ující asimilační proces, nýbrž jako zajišt'ování rovných př́íležitostí s respektem ke kulturní různosti v prostředí společné tolerance“" (cit. podle Crick 2004: 10).

Takto definovaná pluralistická integrace byla od konce 60. let kontinuálně podporována britskými vládami. Nové trendy výrazněji načrtla až imigrační strategie z roku 2002 Secure Borders, Safe Haven: Integration with Diversity in Modern Britain (Home Office 2002). Nadále vychází z toho, že britská společnost je a má být multikulturní. Vedle respektu ke skupinám však zdůrazňuje integraci jednotlivců do jazykové a politické kultury Británie. Posunutí těžiště se projevuje mj. Zavedením slavnostních státoobčanských prrísah pro nově naturalizované občany (první se konaly v únoru 2004).

Současně začala britská vláda intenzivně připravovat program přípravných občanských kurzů. S tímto cílem ustavil tehdejší britský ministr vnitra David Blunkett v září 2002 expertní skupinu Život ve Spojeném království pod vedením profesora Bernarda Cricka. Experti zveřejnili v záŕí 2003 obsáhlou zprávu The New and the Old. The Report of the „Life in the United Kingdom “, která navrhla řadu konkrétních integračních postupů, které zahrnují mj. bezplatnou distribuci příručky Living in the United Kingdom, široké zapojení dobrovolného a privátního sektoru do integrace, včetně ustavení individuálních „,mentorů“ pro imigranty a propracovaného testování jazykových znalostí. Skupina navrhla i obsah kursů občanské výchovy. To již naznačilo, že pohyb dějinného kyvadla směřuje od pluralistické integrace etnických komunit $\mathrm{k}$ občanské integraci jednotlivců.

Skutečnou debatu o multikulturalismu, či přesněji o osudu tohoto termínu, označovaného v diskusích ,slovo M“, otevřel v dubnu roku 2004 předseda britské Komise pro rasovou rovnost ${ }^{14}$ Trevor Phillips v interview pro deník The Times 3. dubna a posléze v projevu 26. dubna (Phillips 2004). ${ }^{15}$ Rozhovor vzbudil pozornost, protože tato Komise byla tradičně 
nejvýraznějším hlasatelem multikulturalismu. Phillips je navíc také považován za spojence Tonyho Blaira a jeho názory jsou proto čteny jako blízké postojům premiéra. V interview pro The Times Phillips tvrdil, že pojem multikulturalismus pochází z jiné éry a již není užitečný, protože naznačuje separaci. V reakci na incident z března 2004, kdy mladí Britové muslimského vyznání spálili britskou vlajku před ústřední mešitou v londýnském Regent’s parku, Phillips také uvedl, že žijeme v jiném světě, než byl svět šedesátých a sedmdesátých let. Dnes je potřeba „např́ic celou společností potvrdit jádro toho, co je britské“ (to assert the core of Britishness). (Později Phillips navrhl zařadit do tohoto jádra např́íklad vládu práva, demokracii, férovost či angličtinu jako společný jazyk.) Podle Phillipse je důležité vzkázat mladým protestujícím muslimům, že jsou považováni za Brity, ale na druhé straně zdůraznit, že být Britem znamená „přizpůsobit se pravidlům britského národa - a ta vylučují terorismus“.

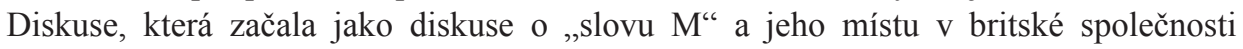
(Phillips 2004), se - podobně jako v Nizozemí - rychle změnila v diskusi o národní identitě a o tom, co znamená být Britem (Connections 2004). Phillips v ní vysvětlil, že Británie podle něj vždy byla a bude rozmanitou společností. Spor nevede s těmi, kdo mají rádi rozmanitost, ale s těmi, ,kdo chtějí fetišizovat historické rozdíly až do té míry, že multikulturalismus v té podobě, v jaké je praktikován, začíná být směšným, nebo se, což je horší, stává nebezpečnou formou zhoubného opomíjení a vyloučeni“" (Connections 2004). Multikulturalismus podle něj znamenal uznání mnoha nových kvalit, které přistěhovalci přinesli do Británie. Dnes ale podle něj „,̌̌elíme novým výzvám, na něž nelze odpovědět starým jazykem vztahů mezi etniky (race). Jedenácté zář́ změnilo svět, a my musíme uznat, že vztahy mezi komunitami nejsou jen o vztazích mezi etniky, ale že jejich předmětem se stává víra“ (Connections 2004).

Phillips podpořil svůj postoj poukazem na skutečnost, že podle zjištění národního statistického úřadu z ledna 2004 popsali čtyři z pěti obyvatel z afro-karibské komunity v Británii svou národní identitu jako „britskou, anglickou, skotskou, velšskou nebo irskou“ a takřka tři čtvrtiny osob indického, pákistánského a bangladéšského původu popsaly svou národní identitu obdobně (Phillips 2004). Ideový př́íklon k občanské integraci ale nejlépe dokládá Phillipsův argument, že „,nárok na rovnost je založen na jistotě našeho občanství. Je založen na tom, co máme společné, nikoli na rozdílech“ (Connections 2004). Z podpory zvláštních skupinových identit se těžiště integrační politiky má přesunout do rekonstrukce „britstvi““ (Britishness) takovým způsobem, aby se stalo etnicky i kulturně inkluzivnějším a zároveň uchovalo a posílilo své politické hodnoty.

Navzdory vášnivosti debaty se podle editora časopisu Connections začal rýsovat společný terén umírněných kritiků i přívrženců „,lova M““. „Nikdo nehájí názor, aby kulturní rozdíly byly srovnány parním válcem nebo aby jim byla upírána hodnota. A nikdo nepopírá potřebu společně sdíleného kodexu“ (Connections 2004). Podobně jako v Nizozemí i britská diskuse ukázala, že současným problémem není soužití etnických, ale náboženských skupin, či přesněji soužití liberální společnosti s fundamentalistickými a sektářskými kř́́dly těchto skupin. Někteří, jako Tariq Modood, profesor na univerzitě v Bristolu, chtějí jen aplikovat model veřejného uznání etnické identity na identitu náboženskou (Modood 2004). ${ }^{16}$ Podle Modooda to znamená, že je potřeba „znovu projednat podmínky integrace“ ve vztahu k britským muslimům. Pokud se však nejedná o problém vztahu $\mathrm{k}$ islámu, ale o problém vztahu $\mathrm{k}$ fundamentalistickému či sektářskému výkladu islámu, pak taková mechanická extenze kulturního uznání 
na muslimskou identitu jako celek míjí svůj cíl. Nemáme totiž primárně co do činění se zděděnou kulturní identitou, ale s jistým ideologicko-náboženským postojem. Problematika se tedy přesunuje z terénu multikulturalismu ke klasické otázce tolerance liberální společnosti vůči netolerantní menšině.

Redefinici integračních strategií a konceptů, který otevřela diskuse o pojmu „,multikulturalismus“, stvrdila v lednu 2005 nová britská vládní strategie pro integraci etnických menšin Improving Opportunity, Strengthening Society: The Government's Strategy to Increase Race Equality and Community Cohesion. Základním kamenem nové strategie je posilování britské identity a pocitu sounáležitosti. Sdílená inkluzivní britská identita (an inclusive sense of Britishness) přitom není v rozporu s kulturní rozmanitostí. „V rozmanité společnosti budou nutně existovat rozdíly v hodnotách a ambicích. Náš respekt ke svobodě znamená, že žádný soubor kulturních hodnot by neměl být upřednostňován před jiným. S výjimkou hodnoty respektu k jiným a zákonnosti, včetně tolerance a vzájemných povinností občanů, které považujeme za základní prvky ,britství', musejí být rozdíly v hodnotách a zvycích řešeny vyjednáváním“ (Home Office 2004: 42). Nejenže koncept „britstvi'“ zahrnuje kolektivní příspěvky, kterými jej obohatila rozmanitá společenství, ale také není výlučnou, exkluzivní identitou. Zatímco všichni občané mají pocit’ovat britskou identitu, ,neznamená to, že musejí volit mezi ,britstvím‘ a jinými kulturními identitami nebo že by měli obětovat své zvláštní životní styly, zvyky nebo víru. Měli by být hrdi na obojí“ (Home Office 2005: 45).

Ve vztahu k novým přistěhovalcům strategie konstatuje, že společenská různost se jejich příchodem stává ještě komplexnější. Spolu s již ustavenými etnickými komunitami vytvářejí nové skupiny imigrantů vysoce heterogenní populaci. Společnost neočekává jejich plnou kulturní asimilaci (ve smyslu opuštění jejich původní skupinové příslušnosti), ale přijetí britské identity. Znalost angličtiny je jedním z předpokladů vytvoření této identity a slavnostní státoobčanská přísaha jejím potvrzením. Strategie tak sice opouští multikulturalismus jako heslo, podržuje však jeho princip duální identity.

\section{Proměny problému integrace: od etnicko-kulturních $\mathrm{k}$ ideologicko- -náboženským konfliktům}

Eskalace napětí mezi muslimskými přistěhovalci a evropskými společnostmi dodala palivo těm, kteří kritizovali př́liš tolerantní přístup Evropanů ke kulturním odlišnostem imigrantů symbolizovaný ,slovem M“. Proti této interpretaci je ovšem třeba připomenout, že země jako Francie a Německo, které se k multikulturalismu nikdy nepřihlásily, mají stejné problémy s muslimskými přistěhovalci jako Velká Británie či Holandsko, které multikulturalismus přijaly jako vládní politiku. Diskuse probíhající v Nizozemí a Británii spíše naznačuje, že výzva fundamentalistického islámu je jiného typu než výzvy, na něž reagují obhájci i kritikové multikulturalismu. Přenáší totiž těžiště z otázky soužití evropských většin s kulturně odlišnými etnickými menšinami k otázce jejich soužití s netolerantními náboženskými či ideologickými menšinami.

Nábožensky motivované konflikty se postupně globalizují - jsou vyvazovány z omezených geografických a kulturních souřadnic. Díky této „,de-teritorializaci“ a „de-kulturalizaci“ přestává být pro jejich analýzu a řešení vhodné etnokulturalistické paradigma. Jak ukázal 
Christian Joppke, mobilizace muslimů v Británii spuštěná Rushdieho aférou roku 1989 začala narážet na etnickou definici skupin, kterou používal britský multikulturalismus: pod definici etnika (race), z níž vycházely antidiskriminační a integrační politiky, spadali sice vedle Pákistánců či Indů také židé či sikhové, nikoliv však muslimové (Joppke 1999). Kvůli etnickému modelu menšin není multikulturalismus schopen řešit konflikty povstávající z př́islušnosti k odlišným univerzalistickým náboženstvím.

Tento typ př́slušnosti se vzpírá také Huntingtonově osnově střetu civilizací. Islamizace každodenního života (čili ,islámský fundamentalismus“ ve vlastním slova smyslu) i islamizace politických programů a postojů (čili ,islamismus“ ve vlastním slova smyslu) u přistěhovalců druhé a třetí generace totiž jdou nejen proti životnímu způsobu evropských společností, ale ve stejné míře také proti tradičním podobám islámu, které si jejich otcové a dědečkové přivezli z neevropských zemí. Konflikty islamizačního hnutí s evropskými společnostmi proto nelze adekvátně zachytit prostřednictvím představy střetu dvou kultur - „,ivilizaci““ -, jejichž neslučitelnost by byla dána tím, že se po staletí rozvíjely nezávisle na sobě. Tyto konflikty jsou naopak spjaty s vytvářením nové islámské identity, která zaplňuje prázdné místo po odumírajících tradicích. Politiky multikulturní integrace, rozvíjené v Británii či Holandsku 70. a 80. let, měly překonávat problémy soužití moderní evropské kultury s tradiční kulturou přistěhovaleckých komunit. Jak se však v posledních letech ukazuje, skutečně nebezpečné není doznívání zděděných tradic (jakkoliv bolestné konflikty přináší), ale tvorba nové skupinové identity, která již není opřena o př́slušnost ke zvláštní etnické skupině $\mathrm{s}$ kořeny $\mathrm{v}$ nostalgicky připomínané domovině, ale o příslušnost ke společenství věrících založeném na zjeveném textu s údajně jednoznačným smyslem, závazným pro všechny lidi. Ve zkratce řečeno: problémem již nejsou skupiny pěstující zvláštni tradice, nýbrž skupiny dovolávající se univerzálnich pravd.

Multikulturalismus do jisté míry úspěšně fungoval jako odpověd' na problém integrace etnokulturních společenství, která přicházela v první fázi poválečné imigrace. Začíná však selhávat ve chvíli, kdy se problémem stává rekonstrukce skupinové identity dalšími generacemi, u nichž jde oslabování př́slušnosti ke komunitě původu ruku v ruce s posilováním př́islušnosti $\mathrm{k}$ islámu. Tuto kvalitativně proměněnou situaci zaznamenávají nedávné výzkumy hnutí islamizace na evropské půdě z pera francouzských sociologů a politologů (Boubeker 2004; Gaspar, Khosrokhavar 1995; Kepel 2002; Roy 2002; Venel 2004). Komunikačním jazykem fundamentalistických a islamistických muslimů ve Francii či Británii dnes nejsou jazyky jejich rodičů, ale francouzština či angličtina. Legitimací pro vstup do jejich „neo-komunity“ (Roy) není rodinný, klanový či etnický původ, ale obrácení se k Bohu, a to může učinit i rodilý Francouz nebo Brit (počet evropských konvertitů mezi fundamentalisty i radikálními islamisty stoupá). Podobně se ani vstup do manželství neřídí tradičními zvykovými pravidly (napríklad věno) a domluvou rodin, ale jeho podmínkou je shoda ženicha a nevěsty v pojetí islámu.

Tato vznikající fundamentalistická subkultura evropského islámu není kulturou v původním etnografickém slova smyslu - tj. generačně předávaným souborem zvyků, představ, rituálů. Mnohem spíše se podobá prakticky realizované ideologii. Každodenní život se má řídit př́kladem Proroka, který je údajně univerzálně aplikovatelný. Jeho platnost se tedy neomezuje na nějaké zvláštní - etnické či lokální - společenství, ale má se stát základem pro společen- 
ství univerzální - ummu. Na rozdíl od tradičních komunit neleží těžiště této obce ve zvycích předávaných automaticky z otců na syny a z matek na dcery v rámci procesů primární socializace v rodinných a př́buzenských strukturách, nýbrž ve vědomém šíření a osvojování idejí, z nichž se racionálně vyvozuje náležitý životní způsob.

Problém integrace je tedy redefinován: nejedná se již o otázku tolerance či uznání etnicko-kulturních, nýbrž ideologicko-náboženských skupin. Mají-li tyto skupiny nepřátelský postoj k základním principům liberální společnosti, jako je svoboda přesvědčení a vyjadřování či rovnost mužů a žen, pak musí liberální většina nahradit toleranci úsilím o jejich ,,asimilaci“ do svých občanských hodnot. Jedná-li se prvotně o ideologický, nikoliv etnický konflikt, je přenesení důrazu z uznání skupinových kultur na individuální občanskou integraci jedinou adekvátní odpovědí. Toto přenesení důrazu nemusí znamenat opuštění multikulturních opatření, která umožňují soužití různých kulturních skupin i udržování jejich tradic - např́iklad výjimky z otevíracích dob či jídla ve školních či závodních jídelnách respektující zvláštní náboženské tradice, prrítomnost neevropských kultur, symbolů i náboženství ve veřejné sféře atd. Větší citlivost a institucionální akomodace vzhledem ke kulturně odlišnému se v posledních desetiletích staly součástí etablovaného mainstreamu západních společností a zrejmě jí zůstanou, i když by se „slovo M“ přestalo používat pro jejich označení. Současný důraz na občanskou jednotu není popřením tohoto mainstreamového multikulturalismu, ale spíše odpovědí na kvalitativně odlišný problém náboženského fundamentalismu.

\section{5. Česko: od multikulturalismu k občanské integraci}

Pro oblast imigračních a integračních politik v České republice znamenal zásadní zlom politický převrat v listopadu 1989. Hranice obehnané ostnatým drátem sice nebyly zcela nepropustné, a také v socialistickém Československu existovala zvláštní forma řízené pracovní migrace, například formou „hostujících dělníkư“ z Vietnamu a jiných zemí tehdejšího komunistického světa. Problém integrace přistěhovalců však byl zcela potlačen: dělníci a učni se museli vrátit do svých zemí a po dobu pobytu zde byli uměle drženi v záměrné společenské izolaci. (To neplatí pro zahraniční vysokoškolské studenty, kteří díky individualizované povaze své činnosti měli daleko větší styk se sociálním okolím.) Po roce 1989 se však situace změnila: „otevření hranic“ a liberální přístup k migraci v první polovině 90 . let usnadnily příchod tisíců imigrantů, a tento přirozený vývoj podmíněný celkovou př́znivou ekonomickou i společenskou situací již nezvrátily ani pozdější snahy o restrikci. Česká republika se - i z úhlu statistik - začala měnit v imigrační zemi. ${ }^{17}$

K zahrnutí cíle integrace přistěhovalců do státní politiky došlo v České republice na konci 90 . let 20. století. U vzniku integrační politiky se setkaly tři rozhodující okolnosti. První byla zřejmá vnitřní potřeba, druhou ochota ministerstva vnitra začít se otázkami integrace zabývat a třetí iniciační role Rady Evropy. Účast Rady Evropy v přípravné fázi tvorby integrační politiky sehrála prritom nejen roli katalyzátoru postupu př́pravy, ale ovlivňovala zpočátku také ideovou výbavu a slovník vládních dokumentů. ${ }^{18}$

Vývoj politik integrace můžeme rozdělit do dvou fází. V první, zakladatelské fázi (1999-2003) spadala tato problematika do působnosti ministerstva vnitra, které zde sehrálo roli osvíceného hybatele. Druhá fáze pak byla zahájena převedením této agendy pod ministerstvo práce a sociálních věcí od 1. ledna roku 2004. 
Prvním uceleným vládním dokumentem byly Zásady koncepce integrace cizinců z roku 1999 (Ministerstvo vnitra ČR 1999). ${ }^{19}$ Ačkoli zásady nejsou žádným multikulturním manifestem, ale dokumentem, který uznává existenci úkolu integrace cizinců, jenž má být naplněn otevíráním rovných příležitostí a aktivním přistupem státních orgánů, můžeme v něm nalézt i ozvěny multikulturního diskurzu. Projevuje se například zavedením pojmu „imigrační komunita“ a přihlášením se „,k budování multikulturní společnosti“. Imigrační komunity, chápány jako společenství, která spojuje historické vědomí, kultura, jazyk, národní identita nebo etnická př́slušnost, jsou „pokládány za integrální a obohacující součást společnosti a plnohodnotné a nezbytné partnery při vytváření multikulturní společnosti“ (zásada č. 2). Vytváření multikulturní společnosti je přitom „„řeba založit na dialogu mezi komunitami, jehož cílem je vzájemné kulturní obohacení". Na druhé straně ale Zásady (respektive vysvětlení k nim podané) podotýkají, že „uznání př́ślušnosti jedince k určité komunitě neznamená, že by s ní jednotlivec měl být vždy a zcela identifikován“. Komunity jsou tak chápány jako dynamická, vyvíjející se společenství, která nelze chápat jako neprodyšně oddělené skupiny.

$\mathrm{Na}$ Zásady navázala mnohem obsáhlejší Koncepce integrace cizinců z roku 2000 (Ministerstvo vnitra ČR 2000). Jestliže ideovým východiskem Zásad byly dokumenty Rady Evropy, do Koncepce se již výrazně promítají dokumenty Evropské unie. Jsou to především tzv. Závěry z Evropské Rady v Tampere (1999), ${ }^{20}$ jejichž klíčovou tezí je požadavek „,přibližování postavení legálně a dlouhodobě usedlých cizinců právnímu postavení občanư“ a posilování rovného př́istupu a rovných př́ležitostí a ochrany před diskriminací.

Role „komunit“ se z Koncepce vytrácí, integrace „každého cizince probíhá individuálně“ a je pojímána jako „začleňování jedince nebo skupiny do života společnosti““. Pokud se objevuje odkaz na komunity, tak jen okrajově. Koncepce např́klad zdůrazňuje, že je potřeba věnovat pozornost postavení žen z přistěhovaleckých komunit (ve společnosti i uvnitř komunity) a požadavku na podporu výzkumu cizineckých komunit. V souvislosti s postavením žen pak Koncepce výslovně uvádí, že ,přes respekt k tradicím a určitým odlišnostem některých kultur není vždy možné a vhodné požadavkům cizinců v oblasti tradic plně vyhovět. [...] Stejně tak není možné tolerovat postoje a chování neslučitelné s českým právním řádem (např. Vynucené sňatky, polygamii, omezování přistupu ke vzdělání a zdravotnictví nebo zákaz zaměstnání, domácí násilí)“ (Ministerstvo vnitra ČR 2000: 23). Výraz „multikulturní“ zůstává klíčovým pojmem jen v oblasti vzdělávání, kdy je navrhována podpora programů multikulturní výchovy.

Výraznější úvahy o multikulturní společnosti nenajdeme ani v navazujících dokumentech, např́klad v Analýze situace postavení cizincủ (2003), kterou zpracovala meziresortní Komise ministra vnitra. ${ }^{21} \mathrm{~V}$ tomto dokumentu jsou v části pojednávající o „kultuře, náboženství a sdělovacích prostředcích" rozlišeny dva modely kulturní integrace: kulturní asimilace a pluralistická kulturní integrace. Ta podle Analýzy předpokládá, ,že v rámci jednoho demokratického státu mohou vzkvétat různé kultury, pokud tyto respektují jednotící a omezující rámce základních práv a hodnot, a pokud jsou samy vnitřně otevřené. Pluralistickou kulturní integraci tak lze definovat jako vzájemné přijetí a respektování odlišností plus sdílení demokratických norem“" (Ministerstvo vnitra ČR 2003: 33).

$\mathrm{V}$ části věnované jazyku je původní jazyk přistěhovalců uznán za nedílnou součást jejich kultury a identity. Společnost by proto měla v rámci svých možností podporovat jeho uchování. Na druhé straně ale zdůrazňuje, že podmínkou úspěšné integrace je zvládnutí jazyka vět- 
šinové společnosti a uvádí, že „neznalost místního jazyka není projevem multikulturality, jak se někdy mylně usuzuje, nýbrž je projevem nedostatku integrace“, a upozorňuje, že ,nedostatečné jazykové znalosti nejsou jen osobním handicapem toho kterého přistěhovalce, ale [...] mají celospolečenské dopady v podobě fragmentace společnosti a segregace celých přistěhovaleckých komunit“" (Ministerstvo vnitra ČR 2003: 35).

Příslibem nových strategických přístupů je první vládní výroční integrační materiál zpracovaný koncem roku 2004 ministerstvem práce a sociálních věcí (Ministerstvo práce ČR 2004). Ministerstvo se zamýšlí nad nedostatky dosavadních př́istupů, jež spatřuje v jejich přílišné obecnosti. Kritizuje, že nejsou vymezeny podmínky úspěšné integrace přistěhovalců. Chybí tak motivační prvek integračního úsilí. Stávající koncepce se soustředí především na přiblížení právního postavení cizinců právnímu postavení občanů, pozitivně však neformuluje svá očekávání. Neukládá žádné povinnosti, pokud jde o integrační opatření, zároveň ale nepřiznává žádné nároky, nezvýhodňuje osoby projevující snahu o začlenění do společnosti. Řešení vidí ministerstvo práce a sociálních věcí v tom, že se Česká republika vydá cestou podrobné právní úpravy integrace imigrantů, jak to učinily jiné země, např́klad Nizozemsko, Dánsko, Finsko, Německo a Rakousko. Dokument se explicitně hlásí k novému evropskému trendu: posílení individuální a individualizované integrace, která již není chápána jako výsledek přirozených a samovolných integračních procesů, jak ji prezentovaly Zásady, ale jako záměrný a uvědomělý proces, který lze také chápat jako uzavření a naplňování „smlouvy“ mezi přistěhovalcem a hostitelskou společností.

Na úrovni vládních strategií tak můžeme pozorovat posuny, které korespondují s vývojem v jiných evropských zemích. To ale již nelze tvrdit o konkrétních politikách a opatřeních v praxi. Stěžejní důvod je prostý: tyto politiky a opatření se teprve s obtížemi a pomalu vytvářejí. A pokud již někde existují, jako v př́padě podpory kulturních a osvětových aktivit přistěhovaleckých sdružení, jsou jejich cíle definovány velmi široce. Zatím se nepodařilo změnit základní právní a institucionální rámce, jež nikterak integraci přistěhovalcům neusnadňují, spíše naopak. Jak konstatuje Analýza postavení cizinců dlouhodobě žijících v ČR a návrh optimalizačních kroků, zpracovaná nezávislými badateli ze společnosti Ivan Gabal Analysis and Consulting pro ministerstvo práce a sociálních věcí (ř́íjen 2004), „mnoho cizinců si zvyklo vnímat dosavadní stav, plný administrativních překážek, drobné diskriminace a dlouhé doby pro získání trvalého pobytu a občanství jako nezájem České republiky o dlouhodobé usazování cizinců‘ (Gabal 2004: 13).

Stejně tak nedošlo zatím $\mathrm{k}$ vyhraněnosti různých názorových proudů v rámci občanské společnosti a veřejného mínění. Např́íklad většina nevládních organizací, které pracují s imigranty, se zatím drží kréda pomoci znevýhodněným a obhajoby lidských práv a do diskusí o úskalích diverzity a integrace se nehrne. Tento postoj je do jisté míry pochopitelný. Je tu obava, že ve veřejné diskusi může lehce nabýt vrchu populistická a xenofobní žurnalistika. ${ }^{22}$ S výjimkou ojedinělých hlasů akademiků tak česká debata o integraci cizinců spí, a to na rozdíl od debaty o pracovní imigraci, která se v posledních dvou letech rozvinula mimo jiné díky provokativnímu článku Václava Klause „Co s přistěhovalci“ (Lidové noviny, 18. 1. 2003) ${ }^{23}$ a také v souvislosti s otázkou stárnutí české populace. V českém kontextu je zatím multikulturalismus spíše tématem diskusí o integraci Romů než o integraci cizinců. 


\section{Závěr}

Současná debata o multikulturalismu v kontextu přistěhovaleckých politik ukazuje, že nový požadavek ,občanské integrace“ neznamená návrat k asimilačním politikám. Nejedná se v něm o znovunastolení „,monokulturalismu“, ale o vymezení minimálního závazného rámce společenské soudržnosti. Je znovuobjevováním a obhajobou ústavních základů liberálních a demokratických národních států ve věku migrace.

Pokud bychom tento požadavek přesto označili za asimilacionismus, pak je to asimilacionismus občanský, vycházející z teze, že podmínkou plné integrace přistěhovalců je, aby přijali liberální občanskou politickou kulturu daného státu. Spíše než o popření multikulturalismu jde o přenesení důrazu v rámci multikulturního konceptu ,jednoty v různosti““. Byl-li předtím položen důraz na různost, nyní je položen na jednotu. To je výsledkem trpce získaného poznání, že různé kulturní skupiny si mohou udržovat a rozvíjet svou zvláštní identitu k prospěchu všech pouze tehdy, respektují-li vyšší kolektivní rámec v podobě občanského národa a jeho liberálních hodnot.

Prosazování těchto hodnot mezi nově příchozími je dnes naléhavější než předtím, nebot' těžiště konfliktů již nespočívá ve sporu tradiční kultury zemí původu s moderní kulturou přijímajících zemí. Takové konflikty stále existují, ale samy se otupují stř́dáním generací. Dnes však Evropané čelí šíření fundamentalistických forem islámu, které jsou stejně neprrátelské původním tradicím přistěhovalců jako liberálním institucím Evropanů. Toto přesunutí konfliktu z etnicko-kulturního na ideologicko-náboženské pole poskytuje pádný důvod k tomu, aby se liberální země daleko aktivněji snažily o asimilaci přistěhovalců do své liberální politické kultury.

\section{Poznámky}

$1 \quad$ Pojem ,politika“ zde používáme k označení souboru opatření a cílů podporovaných státní mocí. Zahrnuje jak situaci, kdy je určitý stav vynucován státem prostřednictvím zákona a sankcí, tak situaci, kdy jsou stanovené cíle dosahovány pouze osvětou či finanční podporou.

2 Pojem původní národy (first nations) dobře vystihuje morální a právní nároky domorodých obyvatel, tj. těch, kteří žili na území před příchodem nových osadníků. ,Jsou to potomci těch, kteří obývali danou zemi nebo území, když přršly národy jiných kultur a etnického původu, které se později staly dominujícími skrze dobytí, okupaci, usazení se nebo jinými prostředky“ (U. N. Fact Sheet No. 9). V terminologii běžné ve střední Evropě bychom tyto skupiny nejspíše označili za tradiční národnostní menšiny. V Kanadě má zvláštní postavení konstitutivního národa rovněž frankofonní komunita. Zahrnutí nových vln migrantů do multikulturní náruče lze považovat za sekundární. Např́klad Zákon o kanadském multikulturalismu z roku 1988 (viz následující poznámka) je opatřen preambulí, která vypočítává hodnoty a východiska, na nichž je multikulturní doktrína vystavěna. Klíčovými jsou: „multikulturní dědictví“, „práva původních národů“ a „oficiální dvojjazyčnost“. Imigrace či imigranti zmíněni nejsou. Zákon pouze odkazuje na rovné postavení všech Kanad’anů, a to jak rodilých Kanad'anů, tak Kanad'anů na základě vlastní volby.

3 Canadian Multiculturalism Act of 1988. An Act on the Preservation and Enhancement of Multiculturalism in Canada (1988, c. 31, assented to 21st July, 1988).

4 Při úvahách o multikulturní politice v Evropě nelze opominout historii evropského kolonialismu. Jak ukazují případy Velké Británie a Nizozemí, multikulturalismus byl přijímán jako odpověd’ na měnící se realitu mateřských zemí způsobenou rozpadem jejich koloniálních držav a následnou 
imigrací části obyvatel bývalých kolonií do metropolí. Multikulturní realitu těchto zemí lze od druhé poloviny 20. století považovat za transformaci (nebo geografické zúžení) multikulturních říší do multikulturních metropolí. Vztah mateřských zemí k imigrantům bývalých kolonií měl vedle politického i etický rozměr, který byl dán pocitem historické odpovědnosti.

5 Ve Švédsku byla politika multikulturalismu přijata roku 1975, přičemž si vytkla za cíl naplnit tři zásady: ,[R]ovnost životní úrovně menšinových skupin a zbytku společnosti, svobodu volby mezi etnickou a švédskou kulturní identitou a zajištění takových vztahů na pracovišti, aby měli všichni prospěch z toho, že pracují dohromady (tzv. partnerství)“"(Wieviorka 1999: 6).

6 Nevelké Nizozemí s 16 miliony obyvatel patří k hustě obydleným zemím světa (388 obyvatel na $\mathrm{km}^{2}$ ). Jestliže tradice tolerance přispívá $\mathrm{k}$ otevřenosti vůči př́íchozím, nedostatek prostoru (a jeho vzácnost, jelikož část je „vydobyta“" na moři) zase umocňuje pocity, že ,„̌lun je plný““.

7 Act of 9 April 1998, containing rules relating to the integration of newcomers to the Netherlands society (Newcomer Integration Act). Enacted in the Hague on 9 April 1998. Published on 12 May 1998.

$8 \quad$ Nizozemský model povinných integračních kurzů začal být rychle přijímám v jiných evropských zemích, např́íklad Finsku, Dánsku, Belgii, Rakousku a Německu.

9 LPF - List Pim Fortuyn. Jednalo se o typickou stranu jednoho vůdce a jednoho tématu.

10 Reforma integrační politiky je vtělena do dvou návrhů zákonů. První, krátký Zákon o integraci cizinců $v$ zahraniči je zpracován jako novela nizozemského cizineckého zákona z roku 2000. Stanovuje, že pro vydání víza, jež má později umožnit trvalé usazení v Nizozemí, jako je tomu naprríklad u rodinných příslušníků již usazených přistěhovalců, je podmínkou jeho vydání doložení základních znalostí holandštiny a nizozemské společnosti. Zákon by se měl stát účinným sítem zejména $v$ príípadě přistěhovalců $\mathrm{z}$ Turecka a Maroka, u nichž se ve značné míře stále udržuje praxe, že nevěsta či ženich jsou vyhledáváni v zemi původu. Podle informací nizozemského ministra pro integraci to představuje v každé z obou skupin až 60000 potenciálních „sňatkových“ imigrantů v nejbližších letech. Dalším zákonem - Zákonem o občanské integraci v Nizozemí - by měl být nahrazen platný zákon o integraci nových přistěhovalců z roku 1998. Návrh se svými východisky i obsahem výrazně liší od zákona z roku 1998. Zatímco zákon z roku 1998 se vztahoval jen na nově prríchozí, kterých je ročně v Nizozemí asi 18000 , nový zákon by se měl vztahovat i na „staré“ přistěhovalce, a to dokonce i na nizozemské občany, celkem až 775000 osob. Výjimka platí pouze pro občany z jiných zemí EU a pro situace, kdy by integrační požadavky narazily na právo EU a mezinárodní závazky. Zákon by také zrušil státem a obcemi nabízené integrační programy. Až na výjimky, jako jsou někteří přistěhovalci žijící ze sociálních dávek a podpory v nezaměstnanosti či ženy v domácnostech, nepředpokládá ani výraznější finanční či jinou pomoc. Je věcí imigranta, aby potřebné znalosti získal na „volném trhu“. Návrh počítá i se systémem sankcí - finančních pokut při nesložení zkoušek ve stanovené lhůtě. Bez integračního testu se přistěhovalci uzavírá cesta k povolení k trvalému pobytu. Zrušení existujícího povolení k pobytu (dočasnému či trvalému) však není uplatňováno jako sankce. Návrhy byly odsouhlaseny nizozemskou vládou v roce 2004 a počátkem roku 2005 byly v dalším legislativním procesu. Současně probíhaly konzultace s Evropskou komisí ohledně jejich slučitelnosti s právem EU.

11 Desetiminutový snímek natočený v angličtině expresivně popisoval domácí násilí vůči muslimským ženám. Scénář k filmu napsala Ayaan Hirsi Ali, členka nizozemského parlamentu somálského původu.

12 V médiích se objevily úvahy, že nebýt vraždy Theo van Gogha, zpráva by nebyla zveřejněna.

13 Theo van Gogh napsal: „Kdykoli myslím na taková vznešená slova jako ,nizozemská kultura“, přichází mi na mysl Spinoza. Nebo fakt, že Voltairovy knihy mohly být tištěny jen v Amsterodamu. Nebo to, že jen zde bylo možné, že Wim T. Schippers [nizozemský spisovatel] mohl zpochybňovat existenci boží a ostře kritizovat věřící v televizi. Že v této zemi mohla být $\mathrm{z}$ veřejných prostředků podpořena 
hra, jež ukazuje psy sledující z pohovky televizi. Že zde byli provos [nizozemští radikálně-levicoví ,provokatéři ‘] již před květnem 68..."(Van Gogh 2001; přeloženo z anglického překladu).

Britská Komise pro rasovou rovnost (Commission for Racial Equality) je nezávislý orgán dohledu nad dodržováním antidiskriminačních předpisů. Stala se vzorem obdobných orgánů nejen v zemích Commonwealthu, ale nakonec i v Evropské unii. Stalo se tak přijetím směrnice o rasové rovnosti (Racial Equality Directive, 43/2000/EC), která požaduje zřizování antidiskriminačních institucí ve všech členských zemích.

15 Již před Phillipsem ale zveřejnil kritický článek s názvem „Too diverse“ editor Prospektu David Goodhart. Goodhart tvrdil, že vysoká diverzita společnosti může ohrozit pocity sounáležitosti daňových poplatníků.

16 Jak dokládá názorně i boj za práva gayů a leseb, veřejné uznání je více než tolerance v privátní, soukromé sféře. V kontextu boje za rovnoprávnost gayů a lesbických žen znamená „tolerance“ zrušení kriminálních sankcí postihujících styk mezi osobami stejného pohlaví. „Uznáním“ je možnost uzavření manželství nebo nějaké formy registrovaného partnerství mezi osobami stejného pohlaví.

17 Ke dni 31. 12. 2004 žilo podle údajů Českého statistického úřadu v České republice 254294 cizinců legálně, tj. na základě povolení k trvalému pobytu nebo dlouhodobému pobytu. V roce 1994 to bylo jen 104343 cizinců. Podrobněji viz stránky českého statistického úřadu: http://www.czso.cz/ciz/ cizinci.nsf/i/pocet_cizincu_v_cr

18 V únoru roku 1998 připravilo ministerstvo vnitra ve spolupráci s Radou Evropy tzv. Národní kulatý stůl na téma vztahů mezi komunitami a v květnu 1999 byl v Praze uspořádán ve spolupráci s Radou Evropy Seminár o strategiích implementace integračnich politik. Národní kulaté stoly byly uskutečněny v zemích Rady Evropy v návaznosti na realizaci projektu „vztahů mezi komunitami“, který zahájila Rada Evropy v roce 1987, a přijaté Zprávy o vztazích mezi komunitami (Community and Ethnic Relations) z roku 1992. V roce 2001 pak ministerstvo vnitra zajistilo překlad a širokou distribuci materiálů Rady Evropy Diversity and Cohesion: New Challenges for the Integration of Immigrants a studie Framework of Integration Policies.

Zásady obsahují celkem 15 stručných tezí, které jsou podrobněji osvětleny v obsáhlejší předkládací zprávě.

20 Závěry Evropské Rady z Tampere vytyčily vůbec první ucelený střednědobý (pětiletý) program Evropské unie pro oblast „vnitřních věcí a spravedlnosti“, který zahrnoval i celou oblast migrace. Na Závěry navázal v roce 2004 schválený „Haagský program“ na léta 2004 až 2009.

Analýza je př́lohou vládního materiálu $k$ realizaci koncepce integrace cizinců v roce 2003. Vláda ji vzala na vědomí usnesením ze dne 11. února 2004 č. 126. Spoluautorka této studie se na zpracování Analýzy podílela jako členka Komise i příslušné pracovní skupiny.

Existují ovšem i nevládní organizace, které usilují o dialog o multikulturalismu, jako je Multikulturní centrum Praha. Výjimkou je také Slovo 21, které se zaměřuje na osvětu a podporuje dialog $\mathrm{s}$ veřejnými orgány.

23 Václav Klaus v tomto článku otevřel otázku údajně vysokých nákladů společností na integraci přistěhovalců a navrhoval zvážení tohoto aspektu při tvorbě imigračních politik. Přednost by tak měla být dána těm potenciálním přistěhovalcům, kteří nejvíce finančně přispějí k pokrytí těchto nákladů. Článek vedl k první širší výměně názorů na téma imigrace na stránkách Lidových novin. 


\section{Literatura}

Bade, K. J. 2004. Evropa v pohybu. Evropské migrace dvou staletí. Praha: Nakladatelství Lidové noviny.

Barša, P. 2004. Imigrační a integrační politika Francie, Velké Británie a Německa po 2. Světové válce. Ústav mezinárodních vztahů. Studijní sešity 2/2004.

Baršová, A. 2004. „Integrace: Svobodná volba nebo povinnost?“ In Integrace cizinců v Evropě. Praha: Občanské sdružení Slovo 21, s. 40-42.

Both, N., Taouati, N. 2004. Holandsko po van Goghovi. Project Syndicate. Listopad. Dostupné z: http://www.project-syndicate.org/commentary/1755/6

Boubeker, A. 2004. Le voile de la mariée. Jeunes musulmanes, voile et projet matrimonial en France. Paris: L'Harmattan.

Buruma, I. 2004. „The Final Cut. After the Filmmakers Murder, the Dutch Creed of Tolerance Has Come Under Siege“. The New Yorker. 22. prosince 2004.

Citron, L., Gowan, R. 2005. European Civic Citizenship and Inclusion Index. British Council Brussels.

Connections 2004. What now for multiculturalism? Dostupné z: http://www.cre.gov.uk/publs/ connections/conn_04wi_multiculturalism.html

Crick, B. 2004. Projev na konferenci Integrace cizinců v Evropě. Slovo 21: 9-10.

Gabal, I. 2004. Analýza postavení cizinců dlouhodobě žijicich v ČR a návrh optimalizačnich kroki. Praha: Ivan Gabal Analysis and Consulting.

Gaspard, F., Khosrokhavar, F. 1995. Le foulard et la République, Paris: La Découverte.

Gerstenfeld, M. 2005. Radical Islam in the Netherlands. A Case Study on Failed European Policy. Jerusalem Center for Public Affairs, Vol. 4, No. 14, 2 January. Dostupné z: http: //www.jcpa.org/brief/brief004-14.htm

Gogh, T. Van. 2001. „Lack of Self-Respect“. Het NRC Handelsblad Cultureel Supplement. 15. 6. (angl. překlad). Dostupné z: http://www.militantislammonitor.org/article/id/349

Joppke, C. 1999. Immigration and the Nation State. The United States, Germany, and Great Britain. Oxford: Oxford University Press.

Joppke, C. 2003. The Retreat of Multiculturalism in the Liberal State. Russell Sage Foundation. Working Paper No. 203.

Kepel, G. 2004. Fitna. Guerre au coeur de l'islam. Paris: Gallimard.

Lechner, F. J. 2002. Globalisation and National Identity in the Netherlands 1980-2000. Department of Sociology, Emory University. (Draft submitted for the presentation at the 2002 ASA meeting.)

Modood, T. 2004/5. „Multiculturalism or Britishness: A False Debate“. Connections. Winter: Dostupné z: http://www.cre.gov.uk/publs/connections/articles/04wi_falsedebate.html

McGuire, S. 2004. „Clash of Civilisations“. Newsweek, 22 November: 36-39.

Phillips, T. 2004. „Britishness and the ,M“ Word“. Projev před „Civil Service Race Equality Network“, 26. dubna. Dostupné z: http://www.cre.gov.uk/publs/connections/conn_04sp_ britishness.html

Roy. O. 2002. L'islam mondialisé, Paris: Ed. du Seuil.

Selm, J. Van. 2003. The Netherlands: Tolerance under Pressure. Město: Migration Information Source. Dostupné z: http://www.migrationinformation.org/Feature/display.cfm?ID=156 
Venel, N. 2004. Musulmans et citoyens. Paris: PUF.

Wieviorka, M. 1999. „Le multiculturalisme est-il une réponse?“ La Revue de la Confédération française démocratique du travail, janvier, no. 16: 3-23.

\section{Dokumenty}

Act of 9 April 1998, containing rules relating to the integration of newcomers to the Netherlands society (Newcomer Integration Act). Enacted in The Hague on 9 April 1998. Published on 12 May 1998.

Amendment of the Aliens Act 2000 (Vreemdelingenwet) in connection with the introduction of an integration requirement for the admittance of certain categories of Aliens (Aliens Integration Abroad Act) (Wet inburgering in het buitenland). (Nizozemí - legislativní návrhy.) 2004.

Canadian Multiculturalism Act of 1988. An Act on the preservation and enhancement of multiculturalism in Canada. (1988, c. 31, assented to $21^{\text {st }}$ July, 1988).

Commonwealth of Australia. 2003. Multicultural Australia: United in Diversity. Updating the 1999 New Agenda for Multicultural Australia: Strategic directions for 2003-2006.

Department of Canadian Heritage. 2002. Annual Report on the Operation of The Canadian Multiculturalism Act 2001-2002. Dostupné z: www.canadianheritage.gc.ca

Department of Canadian Heritage. 2003. Annual Report on the Operation of The Canadian Multiculturalism Act 2002-2003. Dostupné z: www.canadianheritage.gc.ca

Home Office. 2005. Improving Opportunity, Strengthening Society: The Government's strategy to increase race equality and community cohesion.

Home Office. Secretary of the State for the Home Department. 2002. Secure Borders, Safe Haven. Integration with Diversity in Modern Britain. London: The Stationary Office. February 2002.

Ministerstvo práce a sociálních věcí ČR. 2004. Realizace Koncepce integrace cizinců do konce roku 2004 a postup při realizaci Koncepce integrace cizinců v roce 2005. Přijato usnesením vlády ze dne 5. ledna 2005 č. 5. Dostupné z: http://cizinci.mpsv.cz/soubory/ 2e33592ff4e62e3fbf6636c62f2ea142/Usnesen_5_2005.pdf

Ministerstvo vnitra ČR. 1999. Návrh zásad koncepce integrace cizinců na územi České republiky. Usnesení vlády ze dne 7. července 689. Dostupné z: http://cizinci.mpsv.cz/soubory/ 1333592ff4e6183fbf6636c62f01a142/Z_sady_vl_dy_integrace.pdf

Ministerstvo vnitra ČR. 2000. Informace o realizaci zásad koncepce integrace cizincủ na územi České republiky a návrh Koncepce integrace cizinců na územi České republiky. Přijato usnesením vlády ze dne 11. prosince 2000 č. 1266. Dostupné z: http://www.mvcr.cz/ dokumenty/integrace/index.html

Ministerstvo vnitra ČR. 2001. Informace o zkušenostech se zaváděním Koncepce integrace cizinců na území České republiky. Přijato usnesením vlády ze dne 19. prosince 2001 č. 1360.

Ministerstvo vnitra ČR. 2002. Účinnost Koncepce integrace cizinců na území České republiky do roku 2002 a dalši rozvoj této koncepce po vstupu České republiky do Evropské unie. Přijato usnesení vlády ze dne 13. ledna 2003 č. 55.

Ministerstvo vnitra ČR. 2003. Realizace Koncepce integrace cizinců v roce 2003 a její dalši rozvoj se vstupem České republiky do Evropské unie. Přijato usnesením vlády ze dne 11. února 2004 č. 126. 
Ministerstvo vnitra ČR. 2004. Zpráva o situaci v oblasti migrace na území České republiky za rok 2003. Dostupné z: http://www.mvcr.cz/2003/odbor/oamp/zprava03_odbor_info.html

Regulations on civic integration in Dutch Society. Civic Integration Act. (Nizozemí - legislativní návrhy) 2004.

\section{Autor̆i}

Andrea Baršová pracuje na odboru pro lidská práva Úřadu vlády ČR. Zabývá se postavením přistěhovalců a menšin ve společnosti, občanstvím a ochranou lidských práv. Kontakt: barsova@vlada.cz

Pavel Barša přednáší na Filozofické fakultě Univerzity Karlovy a je analytikem Ústavu mezinárodních vztahů. Je autorem několika knih, mj. Politická teorie multikulturalismu (Brno: CDK, 1999) a Západ a islamismus. Střet civilizací, nebo dialog kultur? (Brno: CDK, 2001). Kontakt: barsa@fss.muni.cz 